\title{
Prolactinergic neurons in a protochordate
}

\author{
M. Pestarino \\ Istituto di Anatomia Comparata, Università di Genova, Genova, Italy
}

\begin{abstract}
Summary. Peptidergic neurons have been detected in the cerebral ganglion of the ascidian Styela plicata by means of cytochemical methods. After incubation with a mammalian antibody to human prolactin the perikarya show a strong immunoreactivity. The possible function of prolactin-like peptides in the nervous system of protochordates is discussed.
\end{abstract}

Key words: Prolactinergic neurons - Immunocytochemistry - Cerebral ganglion - Styela plicata

Several investigations have shown that the central nervous system contains peptides that are similar to the pituitary hormones (Krieger and Liotta 1979; Snyder 1980). In particular, prolactin-like immunoreactivity has been detected in the nerve terminals of rat hypothalamus (Fuxe et al. 1977), in the rat brain (Toubeau et al. 1979) and in the brain of the fish Calamoichtys calabaricus (Hansen and Hansen 1982).

In this study ${ }^{1}$ the cerebral ganglion of the ascidian Styela plicata was studied by means of cytochemical and immunocytochemical methods in order to establish the presence of prolactin-like peptides.

\section{Materials and methods}

Specimens of the ascidian Styela plicata (Protochordata) were collected from the water inside the port of Genoa. After dissection, the neural complex was fixed with Bouin's fluid in sea water for $4 \mathrm{~h}$. Then, it was embedded in paraplast and serially sectioned. The sections $(4 \mu \mathrm{m})$ were placed on albumin-coated glass slides and used for the cytochemical and immunocytochemical assays.

Cytochemistry. The following cytochemical tests were used for the detection of neurosecretory substances: Hansen haematoxylin and eosin, Bargmann chrome-haematoxylin, Gomori aldehyde fuchsin with or without permanganate peroxidation, Bodian silver impregnation.

Send offprint requests to: Dr. Mario Pestarino, Istituto di Anatomia Comparata, Università di Genova, Via Balbi 5, I-16126 Genova, Italy

1 A preliminary account of this work was presented to the Bayliss and Starling Society Meeting, 17th-18th December 1982, Liverpool, U.K. (Pestarino and Tagliafierro 1982) 
Immunofluorescence. The indirect immunofluorescence method (Coons et al. 1955) was applied to dewaxed and rehydrated sections. After incubation for $18 \mathrm{~h}$ in a moist chamber at $4^{\circ} \mathrm{C}$ with rabbit antibody to human prolactin (hPRL) (UCB, Bruxelles) (diluted 1:48,000 in $0.04 \mathrm{M}$ phosphate buffered saline-PBS) as the first layer and for $1 \mathrm{~h}$ in a moist chamber at room temperature with FITC-conjugated goat anti-rabbit $\gamma$-globulin (Behring Institute) (diluted $1: 100$ in PBS) as the second, the sections were washed in PBS, mounted with glycerol-PBS $(9: 1, \mathrm{v} / \mathrm{v})$ and examined with a Zeiss epifluorescence microscope.

The specificity of the antibody was tested by absorptions overnight at $4{ }^{\circ} \mathrm{C}$ with different amounts of the following antigens: human thyroid-stimulating hormone (hTSH), human luteinizing hormone (hLH), human follicle-stimulating hormone ( $\mathrm{hFSH})$, human growth hormone $(\mathrm{hGH})$, human chorionic gonadotropin (hCG) and human chorionic gonadotropin $\alpha(\mathrm{hCG} \alpha)$ (UCB, Bruxelles). The results of these tests are shown in Table 1.

Control staining was carried out with: anti-hPRL preabsorbed overnight at $4^{\circ} \mathrm{C}$ with $50 \mu \mathrm{g} / \mathrm{ml}$ diluted antibody of hPRL (UCB, Bruxelles); FITC-conjugated goat anti-rabbit $\gamma$-globulin only.

Sections of rat pituitary were also used as positive controls.

Table 1. Control tests of the specificity of the anti-hPRL performed by immunofluorescence

\begin{tabular}{llllllll}
\hline $\begin{array}{l}\text { Mg antigen/ml } \\
\text { diluted antibody }\end{array}$ & hPRL & hTSH & hLH & hFSH & hGH & hCG & hCG $\alpha$ \\
\hline 0.01 & + & 0 & 0 & 0 & 0 & 0 & 0 \\
0.1 & + & 0 & 0 & 0 & 0 & 0 & 0 \\
1 & ++ & 0 & 0 & 0 & 0 & 0 & 0 \\
10 & ++ & 0 & 0 & 0 & 0 & 0 & 0 \\
50 & ++ & 0 & 0 & 0 & 0 & 0 & 0 \\
\hline
\end{tabular}

0 normal fluorescence; + some reduction; ++ no fluorescence

\section{Results}

The neural complex of S. plicata, placed between the oral and aboral siphons, is an anatomical structure that consists of a cerebral ganglion and of a dorsal epithelial neural gland. In the cortex of the cerebral ganglion, there are several large neurons, while in the medulla there is a network of nerve fibres among which a few small neurons are visible.

In serial sections of cerebral ganglion the cortical perikarya show a strong basophilia and argyrophilia. After incubation with anti-hPRL the same neurons display a yellow-green fluorescence (Fig. 1).

Incubation with anti-hPRL absorbed with hPRL abolishes the specific immunoreactivity of all the neurons. Furthermore, no crossreactivity between hTSH, hLH, hFSH, hGH, hCG, hCG $\alpha$ and the antibody to hPRL can be detected.

\section{Discussion}

In recent years pituitary hormonal peptides have been detected in the central and peripheral nervous system, where they may act as neurotransmitters or neuromodulators (Goossens et al. 1977; Tramu et al. 1977; Watson et al. 1978; Krieger and Liotta 1979; Toubeau et al. 1979). In particular prolactinlike peptides occur in neurons (Hansen and Hansen 1982) and in the net- 


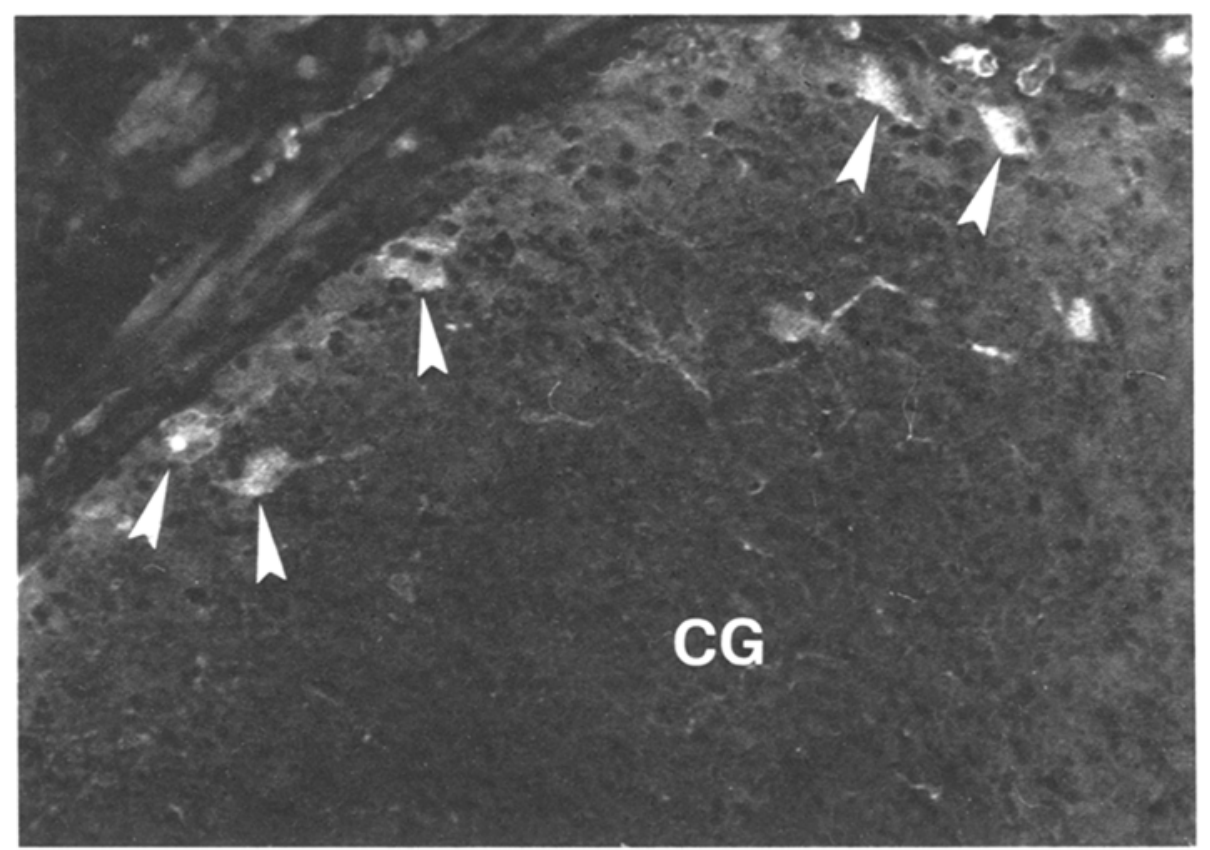

Fig. 1. Part of the cerebral ganglion $(C G)$ in which some immunofluorescent prolactinergic neurons (arrows) are visible. $\times 300$

works of the nerve terminals of some hypothalamic areas of vertebrates (Fuxe et al. 1977).

Ultrastructural and cytochemical investigations have demonstrated also in protochordates the presence of peptidergic neurons. Thus neurosecretory substances have been localized in neurons of Ciona intestinalis (Dawson and Hisaw 1964; Thiebold and Illoul 1965; Chambost 1969), Styela barnharti and Botryllus sp. (Lane 1972). Recently, by means of immunocytochemical tests, ACTH-like (Georges and Dubois 1979), LH-RH-like (Georges and Dubois 1980) and somatostatin-, substance P-, calcitonin-like (Fritsch et al. 1979) peptides have been detected in neurons of $C$. intestinalis. Furthermore, CCK/gastrin-like immunoreactivity has been shown in the nervous system of Styela clava and Ascidiella aspersa (Thorndyke 1982).

The cytoplasmic occurrence of basophilic and argyrophilic materials in neurons of the ascidian $S$. plicata suggests that peptidergic neurons are present in this species, and that these cells contain immunoreactive prolactin-like peptides as demonstrated after incubation with a rabbit antibody against hPRL.

The functions of these pituitary-like peptides in ascidians are still unknown, but one can tentatively assign to them a neurotransmitter role by analogy because of the functions of prolactin in neurons of vertebrates.

The reaction of a mammalian antibody with an ascidian antigen seems to show that the primary antibody used in the present work is extensively specific against ascidian substances. Therefore, we are inclined to think 
that the prolactin molecule has a structure that has changed little in the course of phylogeny.

It is obvious that further immunochemical and biochemical assays are necessary in order to verify structure and function of the ascidian prolactin substances.

\section{References}

Chambost MD (1969) Étude du complexe neural de Ciona intestinalis L. Tethys 1:901-914

Coons AH, Leduc EH, Connolly JM (1955) Studies on antibody production. I. Method for the histochemical demonstration of specific antibody and its application to the study of the hyperimmune rabbit. J Exp Med 102:49-59

Dawson AB, Hisaw FL (1964) The occurrence of neurosecretory cells in the neural ganglia of Tunicates. J Morphol 114:411-424

Fritsch HAR, Van Noorden S, Pearse AGE (1979) Localization of somatostatin-, substance $\mathrm{P}$ - and calcitonin-like immunoreactivity in the neural ganglion of Ciona intestinalis L. (Ascidiaceae). Cell Tissue Res 202:263-274

Fuxe K, Hökfelt T, Eneroth P, Gustafsson JÅ, Skett P (1977) Prolactin-like immunoreactivity: localization in nerve terminals of rat hypothalamus. Science 196:899-900

Georges D, Dubois MP (1979) Immunological evidence for an ACTH-like antigen in the nervous ganglion of a protochordate Ciona intestinalis (Ascidiacea). Arch Anat Microsc Morphol Exp 68:121-125

Georges D, Dubois MP (1980) Mise en évidence par les techniques d'immunofluorescence d'un antigène de type LH-RH dans le système nerveux de Ciona intestinalis (Tunicier ascidiacé). CR Acad Sc Paris Sér D 290:29-31

Goossens N, Dierickx K, Vandesande F (1977) Immunocytochemical localization of vasotocin and isotocin in the preoptico-hypophysial neurosecretory system of Teleosts. Gen Comp Endocrinol 32:371-375

Hansen BL, Hansen GN (1982) Immunocytochemical demonstration of somatotropin-like and prolactin-like activity in the brain of Calamoichtys calabaricus (Actinopterygii). Cell Tissue Res 222:615-627

Krieger DT, Liotta AS (1979) Pituitary hormones in brain: where, how, and why? Science $205: 366-372$

Lane NJ (1972) Neurosecretory cells in the cerebral ganglion of adult Tunicates: fine structure and distribution of phosphatases. J Ultrastruct Res 40:480-497

Pestarino M, Tagliafierro G (1982) Prolactin-like immunoreactivity in the neural gland of a protochordate. Regul Peptides $4: 377$

Snyder SH (1980) Brain peptides as neurotransmitters. Science 209:976-983

Thiebold J, Illoul F (1965) Recherches sur la neurosecretion chez une ascidie Ciona intestinalis L. Bull Soc Hist Nat Afr Nord 56:87-97

Thorndyke MC (1982) Cholecystokinin (CCK)/gastrin-like immunoreactive neurones in the cerebral ganglion of the protochordate ascidians Styela clava and Ascidiella aspersa. Regul Peptides $3: 281-288$

Toubeau G, Desclin J, Parmentier M, Pasteels JL (1979) Compared localizations of prolactinlike and adrenocorticotropin immunoreactivities within the brain of the rat. Neuroendocrinology $29: 374-384$

Tramu G, Leonardelli J, Dubois MP (1977) Immunohistochemical evidence for an ACTH-like substance in hypothalamic LH-RH neurones. Neurosc Letters 6:305-309

Watson SJ, Richard III CW, Barchas JD (1978) Adrenocorticotropin in rat brain: immunocytochemical localization in cells and axons. Science 200:1180-1182 